\title{
Assessment of Soybean Resistance to Leaf-feeding Insect, Spodoptera litura
}

\author{
Ayda Krisnawati*, Nuryati, Mochammad Muchlish Adie \\ Indonesian Legume and Tuber Crops Research Institute (ILETRI), Indonesia. \\ *Corresponding Author: aydakrisnawati@pertanian.go.id
}

Submitted: 2020-06-05. Revised: 2020-10-16. Accepted: 2021-02-23

\begin{abstract}
One of soybean problem in Indonesia is leaf damage caused by the Spodoptera litura. The aim of the study was to identify the resistance of soybean genotypes against army worm based on the preference index and morphophysiological characters. A total of 150 soybean genotypes were grown under field condition from February to May 2018 in Malang (East Java, Indonesia). The preference test was conducted in the laboratory using $\mathrm{G100H}$ as resistant reference plant to armyworm. The result showed that the preference index was ranged from 0.09-1.82. A total of 105 genotypes showed a low preference index (resistant), 39 genotypes showed a high preference index (susceptible), and a genotype has similar preference index with the reference plant (has equal resistance with G100H). Based on the preference index and morphophysiological characters, 150 soybean genotypes can be grouped into eight clusters. A genotype from cluster VIII (Anjasmoro/Rajabasa-41) has characteristics of low leaf water content, dense leaf trichomes, and the preference index of 0.14 . Those characteristics could be the attributes of the soybean genotypes that is resistant to $S$. litura. The Anjasmoro/Rajabasa-41 was recommended to be cultivated in Indonesian, or may be used as a gene source in the breeding program for S. litura resistance.
\end{abstract}

Key words: leaf-feeding pest; preference index; resistant

How to Cite: Krisnawati, A., Nuryati, N., \& Adie, M. M. (2021). Assessment of Soybean Resistance to Leaf-feeding Insect, Spodoptera litura. Biosaintifika: Journal of Biology \& Biology Education, 13(1), 92-98.

DOI: http://dx.doi.org/10.15294/biosaintifika.v13i1.24794

\section{INTRODUCTION}

The armyworm, Spodoptera litura, is the most destructive soybean insect pest in Indonesia. The populations of $S$. litura in soybean cultivated area was highest during the second dry season (June/July September/October). In India, the S. litura population was high in the rainy season and increased in September - October (Babu et al., 2015). The yield loss due to pest attacks can be minimized by using various control methods, such as sex pheromones, biological pesticide such as Bacillus thuringiensis (Bt) and SINPV (Spodoptera litura Nuclear Polyhedrosis Virus), and insecticides (Pratiwi et al., 2016; Bedjo, 2017). The use of insecticides quinalphos $25 \mathrm{EC} 1000 \mathrm{ml} / \mathrm{ha}$ significantly reduced the larval population of leaf eating caterpillar (Dudhbale et al., 2017).

The excessive use of insecticides has caused high levels of insecticide resistance in armyworm (Shad et al., 2012; Tong et al., 2013). The use of resistant varieties is therefore critical for reducing yield losses (Kuswantoro et al., 2017). The use of resistant variety to insects pests is a part of integrated pest management with potential benefits i.e. environmentally friendly, may protect pests' natural enemies, can avoid the emergence of resistance or resurgence, and most importantly are easily adopted by the farmers (Bazok et al., 2011; Bayu et al., 2018).
To develop soybean resistance to armyworm requires the availability of resistant gene for armyworm. The assessment of ten soybean lines for resistance to armyworm in Indonesia have obtained a resistant genotype, G511H/Anj-1-4 (Krisnawati et al., 2017). Furthermore, the evaluation using no-choice test had obtained nine soybean genotypes which categorized as moderately resistant to armyworm (Bayu et al., 2018). In Brazil, an evaluation on four soybean genotypes to $S$. eridania obtained Monsoy 8757 cultivar which most influenced by the prolonged larval, pupal and total cycle length. It had a lower pupal weight and an increase in the reduction of the intrinsic rate (Favetti et al., 2015). Based on Adie et al. (2015), the soybean genotype resistant to armyworm are those being able to restrict the growth and development of armyworm larva and pupa, and prolonged the larval life cycle.

A study on the different host plants of $S$. frugiperda revealed that grasses were the most preferred host for the growth and development of $S$. frugiperda, meanwhile cotton and soybean were less preferred (Silva et al., 2017). Another study on the comparative biology of $S$. litura showed that vegetable soybean was the most preferred by $S$. litura for host plant than the grain soybean. The high biotic potentiality was found on the vegetable soybean when compared to the grain soybean (Naik et al., 2017). Furthermore, Sasane et al. (2018) evaluate the soybean resistance against defoliators based on the 
biophysical characters, and they found that the leaf trichome density was negatively correlated with damage intensity caused by Spodoptera species. In groundnut, a study on the biophysical and biochemical factors associated with resistance to $S$. litura suggested the wax content, phenol content, specific leaf weight, trichome density at midrib and leaf lamina could be used as indirect selection criteria for improving the resistance against $S$. litura (Mohammad et al., 2019). The evaluation of antixenosis resistance on the soybean genotypes which conducted by Xing et al. (2017) used damaged leaf percentage as the indicator. A recent study on the evaluation of soybean resistance showed that leaf color and trichome density were contributed to the antixenosis of Spodoptera cosmioides (de Queiroz et al., 2020). A similar study also indicated that the features of pubescence may contribute to the resistance of soybeans to army worms (Oki et al., 2012).

This research was aimed to identify the soybean resistance against $S$. litura based on the preference index and morphophysiological characters. Finding the level of resistance can be further used to recognize the resistance mechanism of each genotype. In addition, the resistant genotypes found in this study can be used to improve soybean resistance to army worm. The resistant genotypes can be further evaluated for their yield potential, and could be developed in Indonesia as a new variety resistant to armyworm S. litura.

\section{METHOD}

\section{Field study and experimental design}

The field research was conducted on the dry season (February to May 2018) in Kepanjen (Malang, East Java, Indonesia) which located at $8^{\circ} 10^{\prime} 30^{\prime \prime}$ South Latitude and $112^{\circ} 33^{\prime} 32.4^{\prime \prime}$ East Longitude, $335 \mathrm{~m}$ above sea level, C3 (Oldeman) climate type, rainfall $2300 \mathrm{~mm} /$ year, $23.5^{\circ} \mathrm{C}$ minimum temperature, $32^{\circ} \mathrm{C}$ maximum temperature, $79 \%$ relative humidity, and soil type of Alfisol.

The field experiment was laid out in a randomized block design. This study used 150 genotypes with two replications. The research site was in lowland rice with no-tillage. Each genotype was planted in plot size of $1.2 \times 4.0 \mathrm{~m}, 40 \mathrm{~cm} \times 15 \mathrm{~cm}$ plant spacing, two plants per hill. Fertilizer of $50 \mathrm{~kg} / \mathrm{ha}$ Urea, 100 $\mathrm{kg} / \mathrm{ha} \mathrm{SP} 36$ and $75 \mathrm{~kg} / \mathrm{ha} \mathrm{KCl}$ were applied at the sowing time. The pest, disease, and weeds were managed optimally.

\section{Observation}

When plants at 40 days after planting (dap), the trifoliate leaf at the third node of each genotype was detached for the observation of leaf length, width, shape index (ratio of leaf length and width), chlorophyll content, leaf water content, and trichome density. The chlorophyll content was measured by the SPAD 502 Chlorophyll Meter. The leaf water content was determined by following formula (Jin et al., 2017):

Water content $=$

Weight of frash leaves - Waight of dry leaves

Weight of fresh leaves

The visual scoring for leaf trichome density was as follows: $1=$ glabrous/nearly glabrous, $2=$ moderate, and $3=$ dense). The preference of $S$. litura was examined by leaf disc choice test.

\section{The leaf choice test}

The reference plant used was $\mathrm{G} 100 \mathrm{H}$, and the test plants consisted of 150 soybean genotypes. The leaf disc $(\mathrm{d}=1 \mathrm{~cm})$ was derived from the trifoliate leaf in the third node of the reference plant $(\mathrm{G} 100 \mathrm{H})$ and test plant, respectively. In order to preserve humidity, the leaf discs were placed in petri dishes lined with moist filter paper. Each petri dish was contained four leaf discs (two leaf discs of reference and test plant each). Two individuals of $S$. litura second instar were released in each petridish. The experiment was running until $>50 \%$ area of each leaf disc of either test plant or reference plant was consumed by $S$. litura larvae.

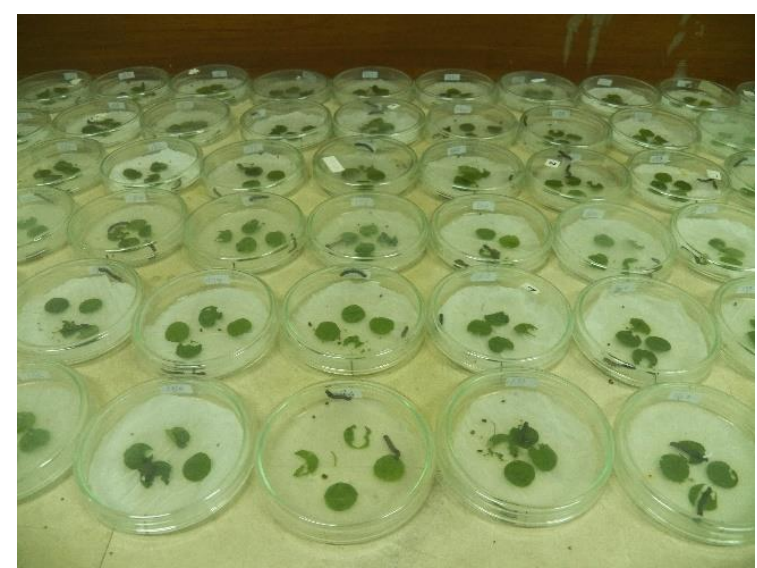

Figure 1. The leaf disc choice test of 150 soybean genotypes in the laboratory.

The preference index was used to compare the test plants with the reference plant. The preference index (C) was calculated according to Oki et al. (2012):

$\mathrm{C}=(2 \mathrm{~A}) /(\mathrm{M}+\mathrm{A})$

Note: $\mathrm{A}=$ Feeding on the test plant

$\mathrm{M}=$ Feeding on the reference plant

$\mathrm{C}<1=$ More resistant (less preferred) than the reference plant, indicates that the test plant has a higher antixenosis resistance than the reference plant 
$\mathrm{C}=1=$ Feeding on the test and reference plant equally

C $>1=$ More susceptible (more preferred) than the reference plant, indicates that the test plant has a lower antixenosis resistance than the reference plant

\section{Data analysis}

Data were subjected to variance analysis (ANOVA). Descriptive data consisted of minimal, maximal, and mean value, as well as the standard deviation. The soybean genotypes were grouping by using cluster analysis of average linkage method, using Minitab ver. 17.1.0 software (Minitab, 2013).

\section{RESULTS AND DISCUSSIONS}

In this study, the soybean leaves for the leaf choice test was derived from the soybean plant leaves in the field. The performance of soybean genotypes in the field is presented in Figure 2a, and the example of soybean leaves in the field attacked by army worm $S$. litura is presented in Figure $2 b$.

In the leaf choice test, the reference plant used as a representative of resistant genotype was $\mathrm{G} 100 \mathrm{H}$.

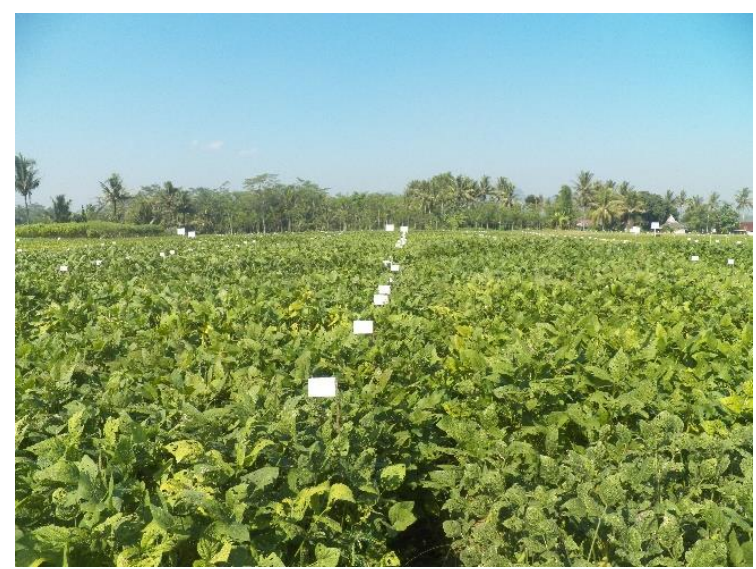

(a)
Earlier study found that $\mathrm{G} 100 \mathrm{H}$ with characteristics of dense and long trichomes was resistant to armyworm (Susanto \& Adie, 2015). In this study, the preference index values and leaf morphophysiology characters (leaf length, width, length and width ratio, chlorophyll content, and trichome density) were significantly affected by differences in soybean genotypes (Table 1). The leaf lengths varied from $7.74-13.09 \mathrm{~cm}(10.89 \mathrm{~cm}$ in average), leaf widths were between $5.57-9.09 \mathrm{~cm}$ (average $7.14 \mathrm{~cm}$ ), while the ratio between length and width ranged from $0.98-1.98$ (average 1.53). Characterization of 150 soybean genotypes based on the leaf shape index (LSI) by Krisnawati \& Adie (2017) showed that most of the genotypes have intermediate leaflet size (110 genotypes), followed by narrow leaflet (23 genotypes), and a broad leaflet (17 genotypes). Furthermore, Chen \& Nelson (2004) reported that the performance of leaflet shape and size of genotypes depends on their geographical origin, for example, the accessions from South Korea showed a smaller size than those from China, Japan, and Russia.

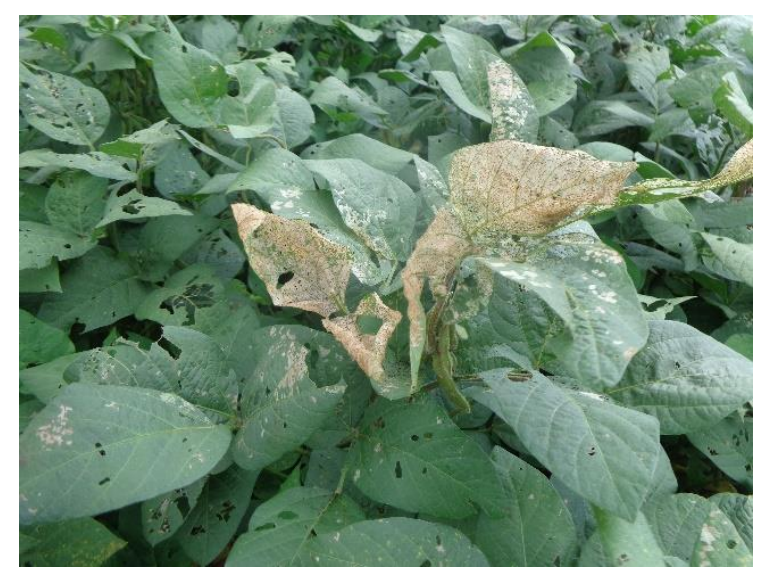

(b)

Figure 2. (a) The performance of 150 soybean genotypes in the field; (b) Soybean leaves in the field attacked by armyworm $S$. litura

Table 1. Analysis of variance for preference index and leaf characters of 150 soybean genotypes

\begin{tabular}{lllll}
\hline No & Character & \multicolumn{2}{l}{ Mean square } & CV (\%) \\
\cline { 3 - 4 } & & Replication & Genotype & \\
\hline 1 & Preference index (C) & 0.0006 & $0.0078 *$ & 2.28 \\
2 & Leaf length (cm) (L) & 0.0038 & $1.6637 *$ & 4.78 \\
3 & Leaf width $(\mathrm{cm})(\mathrm{W})$ & 0.4760 & $0.9253 * *$ & 3.78 \\
4 & Leaf shape index (LSI) & 0.0678 & $0.3142 * *$ & 5.97 \\
5 & Leaf chlorophyll content $(\mathrm{mg} / \mathrm{g})$ & 27.9685 & $22.7764 * *$ & 10.02 \\
6 & Leaf water content (\%) & 82.6980 & $48.2134 *$ & 7.81 \\
7 & Trichome density score & 0.0029 & $0.0482 * *$ & 4.82 \\
$*=$ significant at 5\% probability level $(\mathrm{p}<0.05), * *=$ significant at 1\% probability level $(\mathrm{p}<0.01)$, \\
$\mathrm{CV}=$ coefficient of variation
\end{tabular}


Table 2. Descriptive data of 150 soybean genotypes

\begin{tabular}{lcccc}
\multicolumn{1}{c}{ Character } & Minimal value & Maximal value & Mean & Standard deviation \\
\hline Preference index (C) & 0.09 & 1.82 & 0.73 & 0.41 \\
Leaf length (cm) $(\mathrm{L})$ & 7.74 & 13.09 & 10.89 & 0.91 \\
Leaf width (cm) $(\mathrm{W})$ & 5.57 & 9.09 & 7.14 & 0.68 \\
Leaf shape index (LSI) & 0.98 & 1.98 & 1.53 & 0.16 \\
Leaf chlorophyll content (mg/g) & 27.05 & 42.90 & 34.12 & 3.36 \\
Leaf water content (\%) & 57.97 & 84.82 & 78.98 & 3.96 \\
Trichome density score & 1 & 3 & 2 & 0.52 \\
\hline
\end{tabular}

The leaf chlorophyll content (Figure 3a) varied from 27.05 to $42.90 \mathrm{mg} / \mathrm{g}$ with an average of 34.12 $\mathrm{mg} / \mathrm{g}$. The leaf water content ranged from 57.97 $84.82 \%$ with an average of $78.85 \%$. Dar et al. (2015) reported that the amount of total chlorophyll was correlated with pest resistance in Solanum melongena L. Sasane et al. (2018) found that leaf area and leaf water content were the characteristics of plants associated with the pest resistance in soybean. Among 150 soybean genotypes, 78 genotypes had leaf chlorophyll content over the general mean value. The water contents of 79 genotypes were below the general mean value and the other 71 genotypes were over the general mean value (Figure $3 b$ ).

The leaf trichome is considered as a potential character determining the resistance of soybeans to insect pest (Mitchell et al., 2016). In this study, 77 genotypes had dense trichomes, 69 genotypes had moderate trichome density, and the rests (4 genotypes) had glabrous/nearly glabrous leaf (Figure 3c). Souza et al. (2014) evaluated the resistance of soybean to Spodoptera eridania and found that soybean genotypes IAC 100 and DM 339 were negatively affected the larval and pupal development as well as larval survival but at a lower level. IAC 100 has a dense trichome in both leaves and pods (Suharsono \& Sulistyowati, 2012; Queiroz et al., 2020).

The evaluation of preference index obtained 105 genotypes which were classified as less preferred by $S$. litura larvae or more resistant than resistant reference plant $(\mathrm{G} 100 \mathrm{H}), 39$ genotypes were preferred over $\mathrm{G} 100 \mathrm{H}$, and there was one genotype had the preference index comparable to $\mathrm{G} 100 \mathrm{H}$ (Figure 3d). The evaluation of soybean resistance to $S$. litura using the preference index carried out by Krisnawati et al. (2017) obtained one genotype namely $\mathrm{G} 511 \mathrm{H} /$ Anj-1-4 $(\mathrm{C}=0.57)$ which was considered resistant to $S$ litura, comparable to resistant genotypes of G100H. Souza et al. (2012) using the preference index to examine the soybean resistance to the Spodoptera eridania obtained IAC 100 that was considered very resistant to this pest. Similarly, Couto et al. (2016) examined the preference feeding test of Plutella xylostella for leaves treated with plant extracts. The result showed that the extracts of aqueous and methanolic from $T$. silvatica have high antifeedants activity that caused the lowest consumption of leaf by larvae of $P$. xylostella

Grouping of 150 genotypes based on the preference index and leaf morphophysiological characters is presented in Table 3 and Figure 4. The 150 soybean genotypes were divided into eight clusters. It means that from 150 soybean genotypes tested, one genotype (Anjasmoro/Rajabasa-41) in cluster VIII was classified as the most resistant to $S$. litura due to its lowest preference index. This indicates that that genotype had a higher resistance when compared to the other genotypes.

Several studies obtained soybean resistant genotype to armyworm which was characterized by dense trichomes (Oki et al. 2012; Hendrival et al., 2013; Krisnawati et al., 2017) and low relative water content (Sasane et al., 2018). The dense trichomes may serve as a physical barrier to the feeding and oviposition of insect pests (Mitchell et al., 2016), prevent the attachment of pests and restrict the movement of pests on crops (Tian et al., 2012; Figueiredo et al., 2013). The present result on the low water content trait is also similar to the findings of Nazeem \& Girradi (2011) who reported a positive relationship between leaf relative water content (leaf succulence) and larval population of defoliators, $S$. litura and T. orichalcea. Furthermore, Sasane et al. (2018) concluded that the process of host selection, feeding, ingestion, digestion, mating, oviposition, and leaf use by insect pest may be affected by biophysical traits in plants (leaf relative water content, thickness, area, and trichome density). 


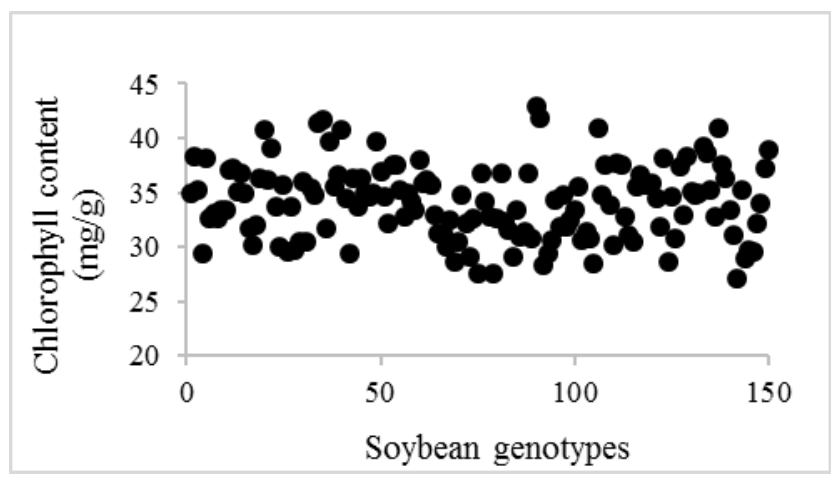

(a)

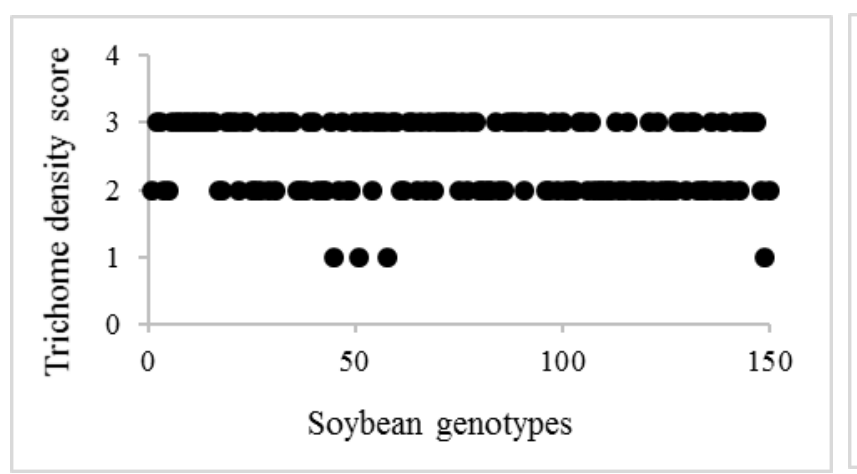

(c)

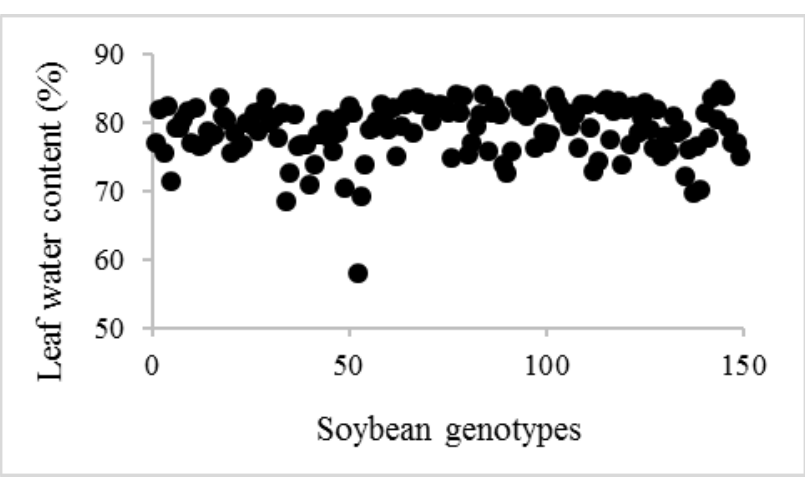

(b)

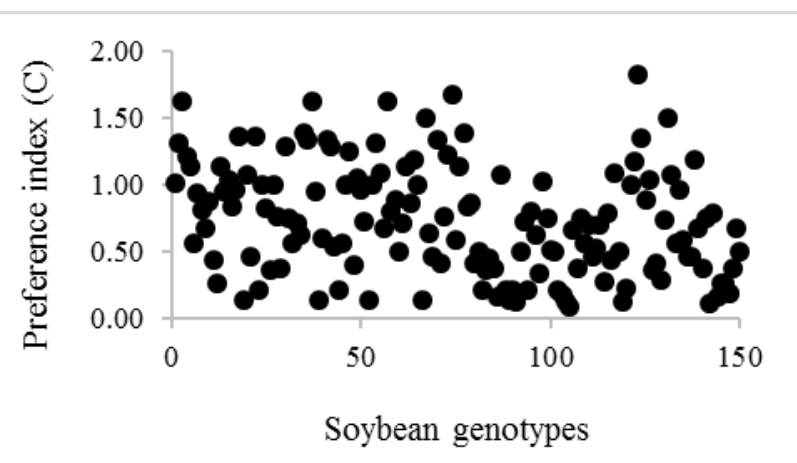

(d)

Figure 3. The leaf chlorophyll content (a), leaf water content (b), trichome density score (c), and preference index (d) of 150 soybean genotypes.

Table 3. Grouping of 150 based on the preference index and leaf morphophysiological characters

\begin{tabular}{|c|c|c|c|c|c|c|c|c|}
\hline \multirow[t]{2}{*}{ Character } & \multicolumn{8}{|c|}{ Cluster } \\
\hline & $\mathrm{I}$ & II & III & IV & $\mathrm{V}$ & VI & VII & VIII \\
\hline Cluster member & 44 & 23 & 27 & 43 & 7 & 4 & 1 & 1 \\
\hline $\begin{array}{l}\text { Preference index } \\
\text { (C) }\end{array}$ & $0.09-1.50$ & $0.36-1.36$ & $0.40-1.62$ & $0.21-1.62$ & $0.46-1.13$ & $0.21-1.39$ & 0.5 & 0.14 \\
\hline $\begin{array}{l}\text { Leaf length }(\mathrm{cm}) \\
\text { (L) }\end{array}$ & $7.74-12.67$ & $\begin{array}{l}9.02- \\
11.58\end{array}$ & $0.41-1.38$ & $\begin{array}{l}10.17- \\
12.92\end{array}$ & $\begin{array}{l}9.25- \\
13.09\end{array}$ & $9.62-11.13$ & 10.59 & 10.75 \\
\hline $\begin{array}{l}\text { Leaf width }(\mathrm{cm}) \\
\text { (W) }\end{array}$ & $5.57-9.09$ & $5.87-7.98$ & $\begin{array}{l}7.80- \\
12.92\end{array}$ & $5.63-8.17$ & $6.54-8.59$ & $6.30-7.82$ & 7.59 & 6.78 \\
\hline $\mathrm{L} / \mathrm{W}$ ratio & $0.98-1.95$ & $1.15-1.62$ & $1.08-1.82$ & $1.30-1.97$ & $1.16-1.64$ & $1.37-1.63$ & 1.39 & 1.58 \\
\hline $\begin{array}{l}\text { Leaf chlorophyll } \\
(\mathrm{mg} / \mathrm{g})\end{array}$ & $\begin{array}{l}27.05- \\
33.40\end{array}$ & $\begin{array}{c}35.30- \\
40.90\end{array}$ & $\begin{array}{l}33.40- \\
37.05\end{array}$ & $\begin{array}{l}29.45- \\
36.20\end{array}$ & $\begin{array}{l}36.30- \\
41.35\end{array}$ & $\begin{array}{l}40.75- \\
42.90\end{array}$ & 38.85 & 32.10 \\
\hline $\begin{array}{l}\text { Leaf water } \\
\text { content }(\%)\end{array}$ & $\begin{array}{l}80.67- \\
84.07\end{array}$ & $\begin{array}{l}72.06- \\
79.37\end{array}$ & $\begin{array}{l}79.82- \\
83.16\end{array}$ & $\begin{array}{l}73.88- \\
80.35\end{array}$ & $\begin{array}{l}68.42- \\
71.54\end{array}$ & $\begin{array}{l}72.77- \\
75.87\end{array}$ & 84.82 & 57.97 \\
\hline $\begin{array}{l}\text { Trichome density } \\
\text { score }\end{array}$ & $2-3$ & $1-3$ & $1-3$ & $1-3$ & $2-3$ & $2-3$ & 2 & 3 \\
\hline Characteristic & $\begin{array}{l}\text { High leaf } \\
\text { water } \\
\text { content }\end{array}$ & $\begin{array}{l}\text { Relatively } \\
\text { high leaf } \\
\text { water } \\
\text { content }\end{array}$ & $\begin{array}{l}\text { Wide } \\
\text { leaves }\end{array}$ & $\begin{array}{l}\text { Long } \\
\text { leaves }\end{array}$ & $\begin{array}{c}\text { Moderate } \\
\text { leaf } \\
\text { water } \\
\text { content }\end{array}$ & $\begin{array}{l}\text { Low leaf } \\
\text { water } \\
\text { content, } \\
\text { high } \\
\text { chlorophyll }\end{array}$ & $\begin{array}{c}\text { High } \\
\text { leaf } \\
\text { water } \\
\text { content, } \\
\text { high } \\
\text { chloro- } \\
\text { phyll }\end{array}$ & $\begin{array}{c}\text { Low leaf } \\
\text { water } \\
\text { content, } \\
\text { dense } \\
\text { trichome, } \\
\text { low } \\
\text { prefe- } \\
\text { rence } \\
\text { index } \\
\end{array}$ \\
\hline
\end{tabular}




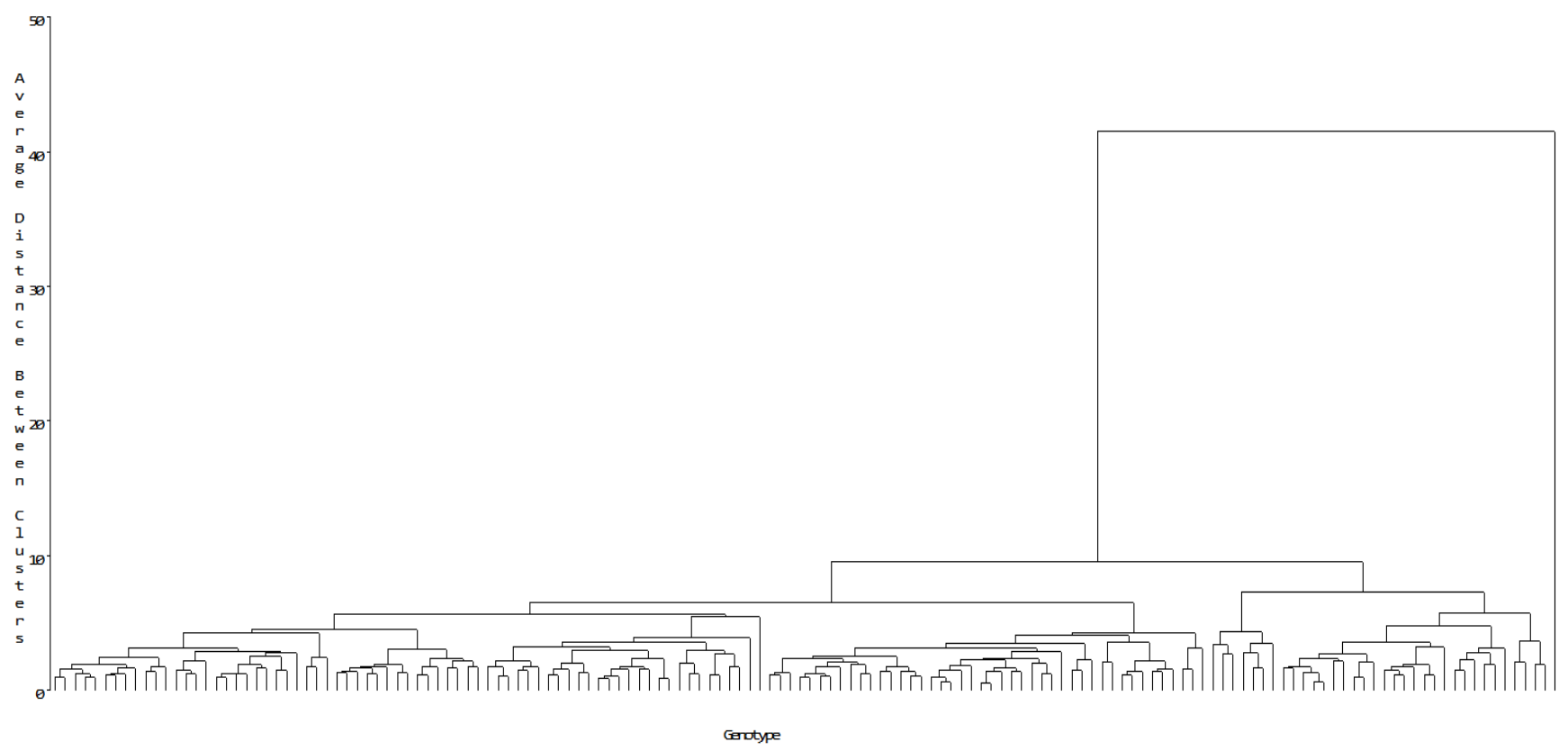

Figure 4. Grouping of 150 based on the preference index and leaf morphophysiological characters

In this study, the Anjasmoro/Rajabasa-41 genotype from cluster VIII showed characteristics of low leaf water content, dense leaf trichomes, and the preference index of 0.14 . Those characters may be the attributes of the soybean genotypes resistant to $S$. litura. The finding from this study suggests that combination of a low leaf water content, dense leaf trichomes, and a low preference index may therefore provide a novel selection criterion for the production of soybean cultivars resistant to insects. A new finding from this study, the Anjasmoro/Rajabasa-41 as a resistant genotype to army worm, can contribute to the science community by using this genotype as a gene source for development of a new resistant variety to army worm $S$. litura or can be released as a new superior variety to be developed in Indonesia. The outcome of this study is also beneficial to farmers, as it is important to use resistant soybean variety to army worm to decrease the yield losses due to $S$. litura.

\section{CONCLUSION}

The soybean resistance to $S$. litura could be increased by using the morphophysiological characters found in soybean leaves as indirect selection criterion. A low preference index, a dense trichome and low water content in leaves are characters that have significant roles in the resistance to $S$. litura. The Anjasmoro/Rajabasa-41 is considered resistant to $S$. litura.

\section{ACKNOWLEDGEMENT}

The authors are grateful to the Indonesian Agency for Agricultural Research and Development (IAARD), Ministry of Agriculture, Republic of Indonesia for funding this research. We also thank Arifin and Antoni who have helped in the collecting the materials and their contribution in the field research.

\section{REFERENCES}

Adie, M.M., Bayu, M.S.Y.I., \& Krisnawati, A. (2015). The variability of resistance of soybean to armyworm. Seminar Proceedings. Indonesian Legume and Tuber Crops Research Institute Malang Indonesia. [in Bahasa]

Ahmed, B.I., \& Yusuf, A.U. (2007). Host-plant resistance: A viable non - chemical and environmentally friendly strategy of controlling stored products pests-a review. Emirates Journal of Food and Agriculture, 19(1), 1-12.

Babu, S.R., Kalyan, R., Ameta, G.S., \& Meghwal, M.L. (2015). Analysis of outbreak of tobacco caterpillar, Spodoptera litura (Fabricius) on soybean. Journal of Agrometeorology, 17(1), 6166.

Bayu, M.S.Y.I., Krisnawati, A., \& Adie, M.M. (2018). Response of soybean genotypes against armyworm, Spodoptera litura based on no-choice test. IOP Conference Series: Earth and Environmental Science, 102, 012033. 
Bedjo. (2017). The potential of various isolates of Spodoptera litura Nuclear Polyhedrosis Viruses from East Java (Indonesia) to control Spodoptera litura on soybean. Biodiversitas, 18(2), 582-588.

Couto, I.F.S., Fuchs, M., Pereira, F.F., Mauad, M., Scalon, S.P.Q., Dresch, D.M., \& Mussury, R.M. (2016). Feeding preference of Plutella xylostella for leaves treated with plant extracts. Annals of the Brazilian Academy of Science, 88(3), 1781-8179.

Dudhbale, C., Surpam, A., Kothikar, R., \& Koche, M. (2017). Bio-efficacy of chemiccal insecticides against Spodoptera infesting soybean. American Journal of Entomology, 1(1), 16-18.

Favetti, B.M., Butnariub, A.R., \& Foersterc, L.A. (2015). Biology and reproductive capacity of Spodoptera eridania (Cramer) (Lepidoptera, Noctuidae) in different soybean cultivars. Revista Brasileira de Entomologia, 59, 89-95.

Haq, I., Amjad, M., Kakakhel, S.A., \& Khokhar, M.A. (2003). Morphological and physiological resistance to insect pests. Asian Journal of Plant Science, 2, 202-204.

Jeong, N., Suh, S.J., Kim, M.H., Lee, S., Moon, J.K., Kim, H.S., \& Jeong, S.C. (2012). Ln is a key regulator of leaflet shape and number of seeds per pod in soybean. The Plant Cell, 24(12), 48074818.

Kogan, M., \& Goeden, R.D. (1970). The host plant range of Lema tritineata daturaphila (Coleoptera: Chrysomelidae). Annals of the Entomological Society of America, 62, 1175-1180.

Komatsu, K., Okuda, S., Takahashi, M., \& Matsunaga, R. (2004). Antibiotic effect of insect resistant soybean on common cutworm (Spodoptera litura) and its inheritance. Breeding Science, 54, 27-32.

Krisnawati, A., \& Adie, M.M. (2017). The leaflet shape variation from several soybean genotypes in Indonesia. Biodiversitas, 18(1), 359-364.

Krisnawati, A., Bayu, M.S.Y.I., \& Adie, M.M. (2017). Identification of soybean genotypes based on antixenosis and antibiosis to the armyworm (Spodoptera litura). Nusantara Bioscience, 9, 164169.

Kuswantoro, H., Bayu, M.S.Y.I., Baliadi, Y., \& Tengkano, W. (2017). Resistance of advanced soybean lines to pod borrer (Etiella zinckenella Treitschke). Biosaintifika: Journal of Biology \& Biology Education, 9(2), 317-324.

Marwoto, \& Bedjo. (1997). Resistancy of armyworm Spodoptera litura to pescticides in the soybean production centers in East Java. p 61-67. In: Nugrahaeni N (Ed.) The Technology Component of Production Increase for Legumes and Tuber
Crops. Seminar Proceedings. Indonesian Legume and Tuber Crops Research Institute Malang Indonesia. [in Bahasa]

McKenzie, J., \& Goldman, R. (2005). The Student Guide to MINITAB Release 14. NY: Pearson Higher Education. Minitab Inc.

Naik, C.M., Nataraj, K., \& Santhoshakumara, G.T. (2017). Comparative biology of Spodoptera litura on vegetable and grain soybean [Glycine max (L.) Merrill]. International Journal of Current Microbiology and Applied Sciences, 6, 366-371.

Pratiwi, K., Trisyono, Y.A., \& Martono, E. (2016). The effect of Bacillus thuringiensis toxin Cry1A.105 and Cry2Ab2 on the survival of the non-target pest, Spodoptera litura. Jurnal Perlindungan Tanaman Indonesia, 20(1), 7-14. [in Bahasa]

Sasane, A.R., Bhalkare, S.K., Rathod, P.K., \& Undirwade, D.B. (2018). Biophysical basis of resistance in soybean genotypes against defoliators. Journal of Entomology and Zoology Studies, 6, 1-7

Shad, S.A., Sayyed, A.H., Fazal, S., Saleem, M.A., Zaka, S.M., \& Ali, M. (2012). Field evolved resistance to carbamates, organophosphates, pyrethroids, and new chemistry insecticides in Spodoptera litura Fab. (Lepidoptera: Noctuidae). Journal of Pest Science, 85, 153-162.

Silva, D.M., Bueno, A.F., Andrade, K., Stecca, C.S., Neves, P.M.O.J., \& de Oliveira, M.C.N. (2017). Biology and nutrition of Spodoptera frugiperda (Lepidoptera: Noctuidae) fed on different food sources. Scientia Agricola, 74, 18-31.

Souza, B.H.S., Boica-Junior, A.L., Janini, J.C., Silva, A.G., \& Rodrigues, N.E.L. (2012). Feeding of Spodoptera eridania (Lepidoptera: Noctuidae) on soybean genotypes. The Revista Colombiana de Entomología, 38, 215-23.

Tong, H., Su, Q., Zhou, X., \& Bai, L. (2013). Field resistance of Spodoptera litura (Lepidoptera: Noctuidae) to organophosphates, pyrethroids, carbamates and four newer chemistry insecticides in Hunan, China. Journal of Pest Science, 86, 599609.

Xing, G., Liu, K., \& Gai, J. (2017). A high-throughput phenotyping procedure for evaluation of antixenosis against common cutworm at early seedling stage in soybean. Plant Methods, 13, 66.

Yang, S., Sun, W., Jianping, L.V., \& Kuang, R. (2009). Use of sex pheromone for control of Spodoptera litura (Lepidoptera: Noctuidae). Journal of the Entomological Research Society, 11(1), 27-36. 